\title{
Article \\ Croton lechleri Extracts as Green Corrosion Inhibitors of Admiralty Brass in Hydrochloric Acid
}

\author{
Carlos Cevallos-Morillo ${ }^{1}\left(\mathbb{D}\right.$, Pablo Cisneros-Pérez ${ }^{2}$, Roxana Llive ${ }^{2}$, Marvin Ricaurte ${ }^{3}$ (D) Carlos Reinoso ${ }^{4}$, \\ Miguel Angel Meneses ${ }^{5}$ (D), Maria del Cisne Guamán ${ }^{5}$ and Alex Palma-Cando ${ }^{3, *(D)}$ \\ 1 Facultad de Ciencias Químicas, Universidad Central del Ecuador, Francisco Viteri s/n y Gato Sobral, \\ Quito 170129, Ecuador; cacevallosm@uce.edu.ec \\ 2 Universidad Regional Amazónica Ikiam, Tena 150102, Ecuador; pablo.cisneros@ikiam.edu.ec (P.C.-P.); \\ wendy.llive@ikiam.edu.ec (R.L.) \\ 3 Grupo de Investigación Aplicada en Materiales y Procesos (GIAMP), School of Chemical Sciences and \\ Engineering, Yachay Tech University, Hda. San José s/n y Proyecto Yachay, Urcuquí 100119, Ecuador; \\ mricaurte@yachaytech.edu.ec \\ 4 School of Physical Sciences and Nanotechnology, Yachay Tech University, Hda. San José s/n y Proyecto \\ Yachay, Urcuquí 100119, Ecuador; creinoso@yachaytech.edu.ec \\ 5 Departamento de Química y Ciencias Exactas, Universidad Técnica Particular de Loja, Loja 110150, Ecuador; \\ mameneses@utpl.edu.ec (M.A.M.); mcguaman@utpl.edu.ec (M.d.C.G.) \\ * Correspondence: apalma@yachaytech.edu.ec
}

Citation: Cevallos-Morillo, C.; Cisneros-Pérez, P.; Llive, R.; Ricaurte, M.; Reinoso, C.; Meneses, M.A.; Guamán, M.d.C.; Palma-Cando, A. Croton lechleri Extracts as Green Corrosion Inhibitors of Admiralty Brass in Hydrochloric Acid. Molecules 2021, 26, 7417. https://doi.org/ $10.3390 /$ molecules 26247417

Academic Editors: Soumen Mandal, Han-Seung Lee and Jitendra Kumar Singh

Received: 17 November 2021 Accepted: 3 December 2021 Published: 7 December 2021

Publisher's Note: MDPI stays neutral with regard to jurisdictional claims in published maps and institutional affiliations.

Copyright: (c) 2021 by the authors. Licensee MDPI, Basel, Switzerland. This article is an open access article distributed under the terms and conditions of the Creative Commons Attribution (CC BY) license (https:// creativecommons.org/licenses/by/ $4.0 /)$.

\begin{abstract}
Croton lechleri, commonly known as Dragon's blood, is a tree cultivated in the northwest Amazon rainforest of Ecuador and Peru. This tree produces a deep red latex which is composed of different natural products such as phenolic compounds, alkaloids, and others. The chemical structures of these natural products found in C. lechleri latex are promising corrosion inhibitors of admiralty brass $(\mathrm{AB})$, due to the number of heteroatoms and $\pi$ structures. In this work, three different extracts of $C$. lechleri latex were obtained, characterized phytochemically, and employed as novel green corrosion inhibitors of $\mathrm{AB}$. The corrosion inhibition efficiency (IE\%) was determined in an aqueous $0.5 \mathrm{M} \mathrm{HCl}$ solution by potentiodynamic polarization (Tafel plots) and electrochemical impedance spectroscopy, measuring current density and charge transfer resistance, respectively. In addition, surface characterization of $\mathrm{AB}$ was performed by scanning electron microscopy, energy-dispersive $\mathrm{X}$-ray spectroscopy, and X-ray photoelectron spectroscopy techniques. Chloroform alkaloid-rich extracts resulted in IE\% of $57 \%$ at $50 \mathrm{ppm}$, attributed to the formation of a layer of organic compounds on the AB surface that hindered the dezincification process. The formulation of corrosion inhibitors from C. lechleri latex allows for the valorization of non-edible natural sources and the diversification of the offer of green corrosion inhibitors for the chemical treatment of heat exchangers.
\end{abstract}

Keywords: corrosion inhibition efficiency; admiralty brass; acid pickling solution; dragon's blood; supercritical $\mathrm{CO}_{2}$ extraction; electrochemical impedance spectroscopy; Tafel plots; linear polarization resistance; XPS; SEM-EDS

\section{Introduction}

Corrosion is the destructive electrochemical attack of a metal by the working environment [1]. The cost of prevention, maintenance, and replacement of damaged infrastructure associated with corrosive processes have been estimated as 5\% of an industrialized nation's gross domestic product (GDP) per year [2]. The design of heat exchangers, which are devices that transfer thermal energy (enthalpy) between two or more fluids [3], requires material with high thermal conductivity and a low coefficient of thermal expansion (CTA). Copper and its alloys are widely used materials for the construction of heat exchangers [4]. Admiralty brass (AB) shows excellent thermal properties (thermal conductivity of $110 \mathrm{~W} / \mathrm{m} \mathrm{K}$ and CTA of $2.02 \times 10^{-5}{ }^{\circ} \mathrm{C}^{-1}$ ) with a nominal chemical composition of $0.04 \%$ As, $71.00 \% \mathrm{Cu}, 1.00 \% \mathrm{Sn}$, and $28.00 \% \mathrm{Zn}$ [5]. However, the negative effects that fouling and 
corrosion products might have on the copper-based heat exchangers are well-document [6]. This issue can be mitigated by periodic cleaning with acid pickling solutions that contain a corrosion inhibitor to reduce or eliminate the destructive effects of the solution on the metal surface. A corrosion inhibitor is a chemical compound that is added in small concentration to a medium to decrease its corrosive nature [1]. The major industries that use inhibited pickling solutions for maintaining heat exchangers are oil and gas exploration and production, crude oil refining, chemical manufacturing, heavy manufacturing, and water desalination and treatment $[7,8]$. The corrosion inhibitor market was valued at $\$ 3.27$ billion worldwide in 2017, with a total consumption of ca. 1.15 million tons [9]. Thiazole, triazole, and tetrazole derivatives are compounds widely employed as a base for the corrosion inhibitors' formulation used in copper heat exchangers [10-14], but these compounds might have adverse effects on health and the environment $[15,16]$. Hence, the identification of green alternatives for corrosion inhibitors is required [17]. Natural products have been studied as corrosion inhibitors for which efficiencies are related to their chemical structure, composed in part by heteroatoms with free electron pairs such as $\mathrm{O}, \mathrm{N}$, and $\mathrm{S}$ capable to bond onto the metal surface $[18,19]$. Natural extracts that contain alkaloids and phenolic compounds have shown corrosion inhibition for mild steels, carbon steels, aluminum, and cooper in acidic media [20-26].

Croton lechleri is a tree of the family Euphorbiaceae, found in the northwest Amazon basin, especially, in the countries of Ecuador and Peru. This tree produces a deep red latex locally known as "Dragon's blood". This latex is used for healing wounds as well as a starting material in the isolation and purification of botanical drugs [27]. The chemical constituents of C. lechleri latex are proanthocyanidins, polyphenolic components [28], alkaloids such as tapsine [29], and minor amounts of terpenoid compounds [30]. Both the alkaloids and phenolic compounds contained in C. lechleri latex should exhibit inhibition corrosion properties on metallic specimens such as $\mathrm{AB}$ in acidic media. The extracts of at least three species of genus Croton have been evaluated as corrosion inhibitors with good results under acidic conditions [31-33].

The extraction of bioactive or functional compounds from vegetable matrices depends on the extraction technique and the solvents used [34]. Lyophilization, solvent and supercritical $\mathrm{CO}_{2}$ extraction are techniques employed to obtain high-quality products, with a good process yield, and low environmental impact [35-37]. Lyophilization is a concentration method that gently removes water from aqueous extracts [38]. It is performed at low temperature and reduced pressure, which eliminates the risks of heat degradation and bumping. In the case of latex samples, it is adequate for obtaining undamaged mixtures of solved and suspended solids. Soxhlet extraction is a classical extraction method for isolating a compound or a determined group of compounds according to the polarity of the solvent employed [34]. Supercritical fluid extraction with $\mathrm{CO}_{2}$ is an alternative non-toxic technique for extracting natural compounds at low temperatures with no use of contaminant solvents [39]. A related technique, named supercritical antisolvent extraction, can assist in overcoming the limited capacity of $\mathrm{CO}_{2}$ to dissolve polar compounds [40], resulting in micro- and nanoparticle-sized products [41].

In this study, we used lyophilization, solvent extraction, and supercritical $\mathrm{CO}_{2}$ antisolvent extraction to obtain $C$. lechleri solid extracts for their characterization as novel green corrosion inhibitors of $\mathrm{AB}$ in hydrochloric acid media. To the best of our knowledge, this is the first report to identify C. lechleri extracts as corrosion inhibitors. Phytochemical characterization of the C. lechleri extracts showed the presence of alkaloid or phenolic compounds. The corrosion inhibition efficiency (IE\%) was electrochemically determined for the three extracts on $\mathrm{AB}$ in hydrochloric acid. The corrosion inhibition mechanism of the extract with the highest inhibition efficiency was studied based on electrochemical impedance spectroscopy (EIS), and superficial analyses, such as scanning electron microscopy (SEM), energy-dispersive X-ray spectroscopy (EDS), and X-ray photoelectronic spectroscopy (XPS), indicating the formation of a protective layer of alkaloids on the $\mathrm{AB}$ surface. 


\section{Materials and Methods}

\subsection{Lyophilization of C. lechleri Latex (CL1)}

A total of $500 \mathrm{~mL}$ of Dragon's blood was purchased from local producers from Tamiahurco village, Napo province, Ecuador. Six samples of $50 \mathrm{~mL}$ of $C$. lechleri latex were cooled at $-60{ }^{\circ} \mathrm{C}$ in an ultra-freezer. Later, they were placed in a lyophilizer (SP ScientificGenevac, BTP-9E LOVE, Stone Ridge, NY, USA) for five days until constant mass to produce a red-brown solid.

\subsection{Chloroform Extract from C. lechleri Latex (CL2)}

The $100 \mathrm{~mL}$ of $\mathrm{C}$. lechleri latex was adjusted to $\mathrm{pH} 11$ with $\mathrm{KOH}$ pellets $(85 \%$, Fisher Scientific, Pittsburgh, PA, USA). After cooling down the mixture at $3{ }^{\circ} \mathrm{C}$ overnight, the resulting red-brown solid was submitted to Soxhlet extraction with $250 \mathrm{~mL}$ of chloroform (ACS, EMSURE ${ }^{\circledR}$ ) for $12 \mathrm{~h}$, twice. Then, the solvent was evaporated under reduced pressure, yielding a beige solid.

\subsection{Supercritical $\mathrm{CO}_{2}$ Antisolvent Extraction from C. lechleri Latex (CL3)}

After lyophilization of the C. lechleri latex, $30 \mathrm{~g}$ of freeze-dried C. Lechleri underwent dynamic maceration with $500 \mathrm{~mL}$ of ethanol at atmospheric pressure and at $20{ }^{\circ} \mathrm{C}$ for $19 \mathrm{~h}$. The final concentration of the ethanolic extract was adjusted to $30 \mathrm{mg} / \mathrm{mL}$ by vacuum evaporation. Then, $\mathrm{CO}_{2}$ flowed continuously at $10 \mathrm{~L} / \mathrm{min}$ (atmospheric conditions) in a precipitator vessel at supercritical conditions $\left(90 \mathrm{bar}, 35^{\circ} \mathrm{C}\right)$. Simultaneously, the ethanolic extract was allowed to flow at $1 \mathrm{~mL} / \mathrm{min}$ through a $1 \mathrm{~mm}$ nozzle. When the supercritical $\mathrm{CO}_{2}$ and the ethanolic extract were in contact, an antisolvent extraction occurred (see Figure S1). The solvent and soluble compounds were extracted in the supercritical mixture of $\mathrm{CO}_{2}$-ethanol (waste) while the non-soluble compounds precipitated as dry particulate pink solid.

\subsection{Quantitative Determination of Alkaloids in the Extracts from C. lechleri Latex}

Then, $100 \mathrm{~mL}$ solutions were prepared with distilled water with concentrations of $1 \mathrm{mg} / \mathrm{mL}, 0.1 \mathrm{mg} / \mathrm{mL}$ and $0.5 \mathrm{mg} / \mathrm{mL}$ for CL1, CL2 and CL3, respectively. Sample CL1 was subjected to a previous treatment whereby $10 \mathrm{~mL}$ of CL1 solution was adjusted at $\mathrm{pH} 2$ with $2 \mathrm{M} \mathrm{HCl}$ followed by rinsing with 3 portions of $\mathrm{CHCl}_{3}$ and $\mathrm{pH}$ adjusting of the aqueous phase at 7 , with $0.1 \mathrm{M} \mathrm{NaOH}$. Then, $5 \mathrm{~mL}$ of CL1, CL2 and CL3 solutions were mixed with $5 \mathrm{~mL}$ of phosphate-buffered solution at $\mathrm{pH} 4.7$ (prepared with $0.2 \mathrm{M}$ sodium phosphate (96\%, Sigma-Aldrich, Burlington, MA, USA)) and $0.2 \mathrm{M}$ citric acid ( $>99.5 \%$, Sigma-Aldrich) into a separatory funnel. After adding $5 \mathrm{~mL}$ of $0.1 \mathrm{mM}$ bromocresol green (95\%, Lobal Chemie, Mumbai, India) solution, four portions of $\mathrm{CHCl}_{3}$ were placed in the following order: $1 \mathrm{~mL}, 2 \mathrm{~mL}, 3 \mathrm{~mL}$, and $4 \mathrm{~mL}$. The resulting mixtures were shaken for $30 \mathrm{~min}$ in an automatic shaker. The organic phases were collected and dried over anhydrous magnesium sulphate and filtered. The resulting solution was poured in a $10 \mathrm{~mL}$ volumetric flask and the volume was completed with $\mathrm{CHCl}_{3}$. The total alkaloid content was determined by spectrophotometry UV-vis (Shimadzu, UV-3600 Plus, Kyoto, Japan) at $416 \mathrm{~nm}$ using an atropine ( $>99 \%$, Sigma-Aldrich, Burlington, MA, USA) standard curve $(0-12 \mu \mathrm{g} / \mathrm{mL})$. Alkaloid values were expressed as atropine equivalents $\mathrm{wt} \%$ of extract.

\subsection{Determination of Total Phenols Content in the Extracts from C. lechleri Latex}

Additionally, $10 \mathrm{mg}$ of CL extracts were dissolved in $70 \% \mathrm{MeOH}$ (ACS, EMSURE ${ }^{\circledR}$ ). An aliquot of $0.5 \mathrm{~mL}$ of this solution was poured in a $10 \mathrm{~mL}$ volumetric flask. Then, $2 \mathrm{~mL}$ of Folin-Ciocalteu reagent ( $2 \mathrm{M}$, Sigma-Aldrich, Burlington, MA, USA) were added. The mixture was agitated for $2 \mathrm{~min}$, followed by $5 \mathrm{~min}$ repose. Then, $1 \mathrm{~mL}$ of $20 \% \mathrm{Na}_{2} \mathrm{CO}_{3}$ ( $>99.5 \%$, Sigma-Aldrich, Burlington, MA, USA) was added, and the volume was completed with $70 \% \mathrm{MeOH}$. The resulting mixture was left in the dark for $2 \mathrm{~h}$. Finally, the total phenols content was determined by spectrophotometry UV-vis in the absorbance maximum of gallic 
acid (97.5-102.5\%, Sigma Aldrich) standard curve $(0-10 \mu \mathrm{g} / \mathrm{mL})$. Total phenols values were expressed as gallic acid equivalents $\mathrm{w} t \%$ of extract.

2.6. Electrochemical Determination of the Corrosion Inhibition Efficiency for the Extracts from C. lechleri Latex

Electrochemical measurements were made with potentiostats/galvanostats Autolab PGSTAT128N and Autolab MAC (Metrohm AG, Herisau, Switzerland), employing a threeelectrode cell. Experiments were run with Nova 2.1. software. The working electrodes were made of copper admiralty (alloy C44300, nominal chemical composition of $0.0030 \%$ $\mathrm{Pb}, 0.0350 \% \mathrm{Fe}, 0.0430 \% \mathrm{As}, 71.8500 \% \mathrm{Cu}, 1.0300 \% \mathrm{Sn}$, and $27.0000 \%$ Zn, Metal Samples, Co., Inc., Munford, AL, USA) with an exposed area of $0.283 \mathrm{~cm}^{2}$. After the specimen were mechanically ground with 220,500, 1000, and 2000 emery paper, they were polished with $0.3 \mu \mathrm{m}$ alumina and washed with ethanol and type I water, then dried, and placed in a cell. $\mathrm{A} \mathrm{Ag}^{0} / \mathrm{AgCl} / \mathrm{KCl} 3 \mathrm{M}$ electrode (CHI111P, CH Instruments, Inc., Bee Cave, TX, USA) and a titanium plate were used as a reference and counter electrodes, respectively. Tafel essays were made by measuring the open circuit potential (OCP) for at least 1800 seconds. Then, a dynamic potential perturbation was applied from $-200 \mathrm{mV}$ to $200 \mathrm{mV}$ vs. OCP at a scan rate of $0.5 \mathrm{mV} / \mathrm{s}$. Electrochemical impedance spectroscopy essays were conducted polarizing the working electrode with an alternating signal of $5 \mathrm{mV}$ amplitude, at the OCP, with frequencies from $0.1 \mathrm{~Hz}$ to $0.5 \mathrm{MHz}$. Data were analyzed employing Zview(R) and Origin 8.1. software.

\subsection{Superficial Characterization of AB Electrodes}

All samples were cleaned using compressed air to remove loose particles and other contaminants and placed in a charge-reduction sample holder. SEM micrographs and EDS spectra were measured with a Phenom ProX (Thermo Fisher Scientific, Waltham, MA, USA) with an acceleration voltage of $15.0 \mathrm{kV}$ at 0.5 mbar.

X-ray photoelectron spectroscopy was performed using PHI VersaProbe III (Physical Electronics), equipped with a 180 hemispherical electron energy analyzer, using a monochromatized $\mathrm{Al} \mathrm{K} \alpha$ source with energy $1486.6 \mathrm{eV}$. Energies bandpass of $255 \mathrm{kV}$ and $55 \mathrm{kV}$ were used for Survey and high-resolution operation. The spot size diameter was $100 \mu \mathrm{m}$. The polished AB sample was cleaned using a sputtering Ar gun for 3 min to remove carbon and oxidized material.

\section{Results and Discussion}

\subsection{Phytochemical Screening of the Extracts from C. lechleri Latex}

Three different techniques were used to obtain solid extracts from the latex of $C$. lechleri (see Figure S2). Lyophilization of the latex of C. lechleri produced a red-brown solid (CL1) with an $18 \mathrm{wt} \%$ yield. Chloroform Soxhlet extraction yielded a $0.17 \mathrm{wt} \%$ beige solid (CL2), while the supercritical $\mathrm{CO}_{2}$ antisolvent extraction gave $1.84 \mathrm{wt} \%$ of a pink solid (CL3). Table 1 shows the alkaloid and phenolic compound contents for the three extracts. CL1 and CL3 are phenolic-rich extracts with $46.5 \mathrm{wt} \%$ and $52.2 \mathrm{wt} \%$, respectively. CL2 is an alkaloid-rich extract with $51.9 \mathrm{wt} \%$ content. Extract CL1 showed both kinds of natural products, while extracts CL2 and CL3 were intentionally enriched in alkaloids and phenolic compounds, respectively. Extract CL2 was obtained after adjusting to alkaline con-ditions $(\mathrm{pH}=11)$, which favored the extraction of alkaloids using chloroform [42]. On the other hand, the sample of the latex of C. lechleri was pretreated with ethanol to obtain CL3, which favored the extraction of phenolic compounds [28]. 
Table 1. Alkaloids and phenolic compounds content for triplicated measurements of the solid extracts obtained from the C. lechleri latex.

\begin{tabular}{ccc}
\hline Entry & Alkaloid Content (wt. \%) & Phenolic Compound Content (wt. \%) \\
\hline CL1 & $2.1 \pm 0.1$ & $46.5 \pm 1.9$ \\
CL2 & $51.9 \pm 1.2$ & $3.7 \pm 0.2$ \\
CL3 & $0.7 \pm 0.4$ & $52.2 \pm 0.4$ \\
\hline
\end{tabular}

\subsection{Potentiodynamic Polarization Plots of $A B$ in $\mathrm{HCl}$ Media with the Extracts from \\ C. lechleri Latex}

Figure 1 shows the potentiodynamic polarization curves for $\mathrm{AB}$ in $0.5 \mathrm{M}$ hydrochloric acid aqueous solution at $25^{\circ} \mathrm{C}$ employing the three different extracts from $\mathrm{C}$. lechleri latex CL1, CL2, and CL3 at a concentration of 300 ppm, 50 ppm, and 200 ppm, respectively. The solubility limit was reached for the three extracts under the working conditions. In all cases, the corrosion current density decreased with the presence of the extracts, which indicates the corrosion inhibition on the surface of $\mathrm{AB}$. These $C$. lechleri extracts could be classified as a mixed-type inhibitor because of a remarkable decrease in the cathodic as well as corrosion currents, with a slight decrease in the anodic currents and shift in the corrosion potential $\left(\mathrm{E}_{\mathrm{corr}}\right)$ to lower values $[43,44]$. This effect significantly increased with increased concentrations of CL3 from 50 ppm to 200 ppm (see Figure S3).

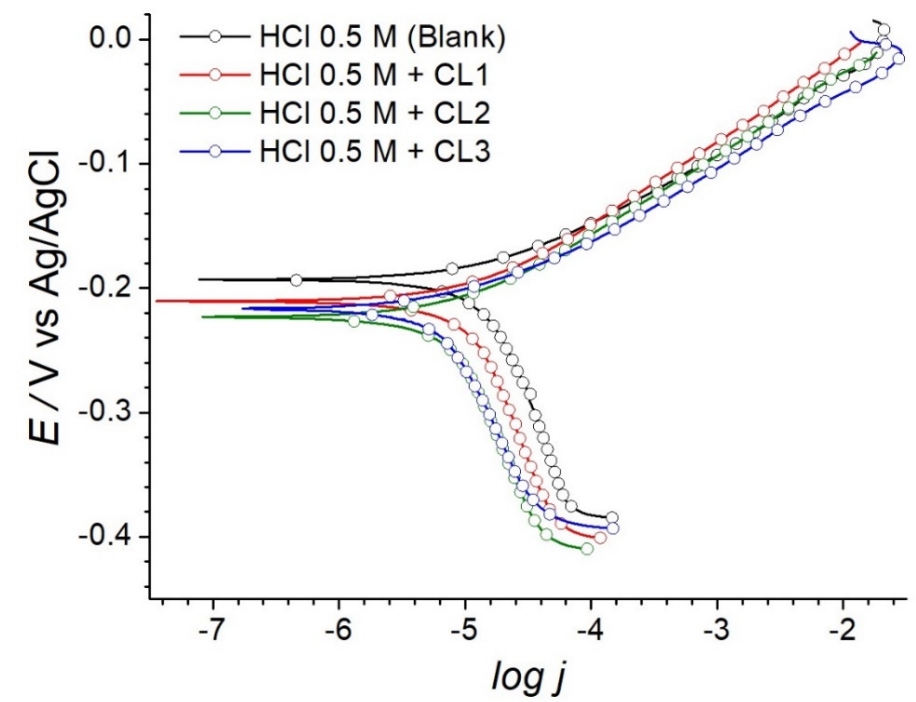

Figure 1. Potentiodynamic polarization plots of $\mathrm{AB}$ in $0.5 \mathrm{M} \mathrm{HCl}$ in the presence of various extracts of extracts from C. lechleri latex at $25^{\circ} \mathrm{C}$.

Electrochemical parameters, including $\mathrm{E}_{\mathrm{corr}}$, cathodic Tafel slope $\left(\beta_{\mathrm{c}}\right)$, anodic Tafel slope $\left(\beta_{\mathrm{a}}\right)$, corrosion current density $\left(\mathrm{j}_{\mathrm{corr}}\right)$, and IE\% are provided in Table 2 . The $\mathrm{j}_{\text {corr }}$ and $E_{c o r r}$ were obtained from the extrapolation of anodic and cathodic Tafel linearized current regions. Values of IE\% were determined using Equation (1) as follows:

$$
\mathrm{IE} \%=\left(1-\frac{\mathrm{j}_{\text {corr }}}{\mathrm{j}_{\text {corr }}^{0}}\right) \times 100
$$

where $j_{\text {corr }}^{0}$ and $j_{\text {corr }}$ represent the corrosion current densities in the absence and presence of inhibitor, respectively. CL1 inhibited in $30.48 \%$ the corrosion of $\mathrm{AB}$ in $\mathrm{HCl}$ media. The CL3 sample showed an improved inhibition of $48.93 \%$ compared to CL1, despite its lower concentration. This result might be related to a higher phenolics content and compound purification due to the supercritical antisolvent process [45]. Moreover, the size and the spheric shape of the particles obtained in CL3, which showed diameters of about 300-600 nm (see 
Figure S4), might increase the surface coverage area and availability compared to the coarse CL1 powder [46-48]. The IE\% was found to increase continuously with an increase in the concentration of CL3 (see Table S2). The highest inhibition efficiency of $51.57 \%$ was reached with the alkaloid-rich CL2 in a low concentration of $50 \mathrm{ppm}$. The use of biomolecules for the formulation of corrosion inhibitors is expected to have a lower environmental impact compared to commercial inhibitors from chemical synthesis [49]. Hereafter, we focused on CL2 for further analysis to develop better insight into the inhibition process.

Table 2. Tafel polarization parameters for $\mathrm{AB}$ in $0.5 \mathrm{M} \mathrm{HCl}$ with extracts from C. lechleri latex at $25^{\circ} \mathrm{C}$.

\begin{tabular}{cccccc}
\hline Entry & $\mathbf{E}_{\text {corr }}(\mathbf{V})$ & $\beta_{\mathbf{c}}(\mathbf{m V} / \mathbf{d e c})$ & $\beta_{\mathbf{a}}(\mathbf{m V} / \mathbf{d e c})$ & $\mathbf{j}_{\text {corr }}\left(\boldsymbol{\mu} \mathbf{A} / \mathbf{c m}^{\mathbf{2}}\right)$ & IE $\%$ \\
\hline HCl 0.5 M & -0.193 & 281.6 & 53.8 & 14.84 & - \\
HCl 0.5 M + CL1 & -0.210 & 261.5 & 62.9 & 10.32 & 30.48 \\
HCl 0.5 M + CL2 & -0.211 & 241.5 & 57.5 & 7.19 & 51.57 \\
HCl 0.5 M + CL3 & -0.214 & 238.0 & 47.5 & 7.58 & 48.93 \\
\hline
\end{tabular}

\subsection{EIS of $A B$ in $\mathrm{HCl}$ Media Inhibited with CL2}

After Tafel measurements, EIS was carried out by varying the frequency from $0.1 \mathrm{~Hz}$ to $0.5 \mathrm{MHz}$. Equation (2) was used to calculate IE\% as follows:

$$
\mathrm{IE} \%=\left(1-\frac{\mathrm{R}_{\mathrm{ct}}^{0}}{\mathrm{R}_{\mathrm{ct}}}\right) \times 100
$$

where $\mathrm{R}_{\mathrm{ct}}^{0}$ and $\mathrm{R}_{\mathrm{ct}}$ represent the charge transfer resistance in the absence and presence of CL2, respectively. Figure 2 shows the impedance diagrams obtained in the presence and absence of $50 \mathrm{ppm}$ of CL2 at $\mathrm{E}_{\text {corr }}$ in $\mathrm{HCl} 0.5 \mathrm{M}$. The Nyquist plot reveals one loop at high frequencies (see Figure 2a inset). A second loop is observed at middle frequencies and the beginning of a diffusional impedance for both spectra (see Figure 2a). All loops are distorted semicircles. Deviations of the ideal semicircles can be attributed to the inhomogeneities on the alloy surface such as point defects, grain boundaries, and lattice distortions [50]. Independent of the polishing treatment, the admiralty surface formed oxide films by the contact of the metallic electrode with atmospheric or dissolved oxygen. This thin oxide layer is observed in the Nyquist plot as one loop at high frequencies.
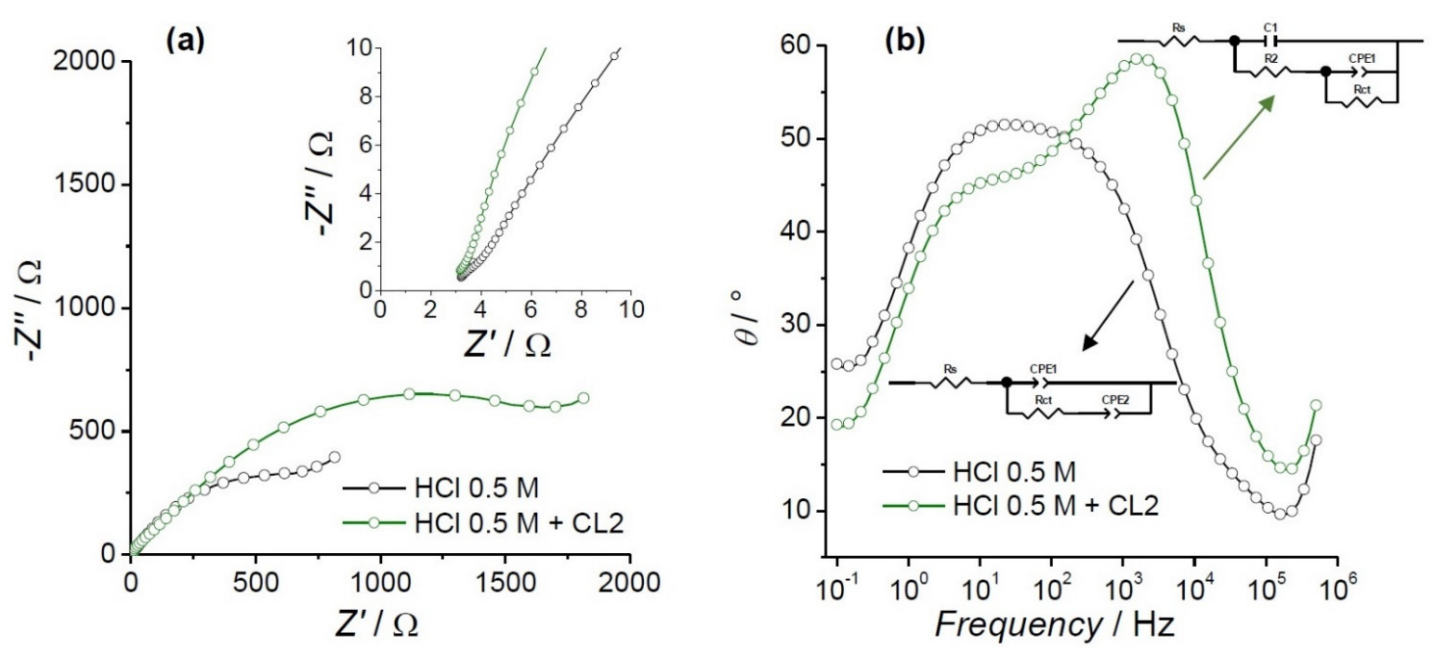

Figure 2. Electrochemical impedance spectroscopy diagrams of $\mathrm{AB}$ at $\mathrm{E}_{\mathrm{corr}}$ in $0.5 \mathrm{M} \mathrm{HCl}$, in the absence (black lines) and the presence (green lines) of CL2: (a) Nyquist plots (inset: zoom in at high frequencies) and (b) Bode diagrams (insets: equivalent circuits). 
The Nyquist spectra with and without the inhibitor were fitted using equivalent circuits (see Figure $2 b$ insets), where $R_{s}$ is the solution resistance, $R_{c t}$ is the charge transfer resistance, CPE1 and CPE2 are constant phase elements, $\mathrm{R} 2$ is the oxide film resistance, and $\mathrm{C} 1$ the capacitance for the oxide film. EIS fitting parameters are summarized in Table 3. For $\mathrm{AB}$ in $\mathrm{HCl}$ media, a CPE1 of $496.6(\mu \mathrm{F})^{\mathrm{n}}$ was obtained with a value of $\mathrm{n}=0.63$, describing the behavior of the capacitor, while a value of $6.29(\mathrm{mF})^{\mathrm{n}}$ was determined with $\mathrm{n}=1.13$ for the CPE2. For the impedance spectra, fitting in the presence of CL2, C1 was found to have a value of $3.45 \mu \mathrm{F}$. This circuit is composed of two-time constants nested, which indicate a porous or inhomogeneous layer onto the $\mathrm{AB}$ where the charge transfer occurs (see Figure 2b) [12]. Similar behavior was observed in a set of trials performed with different concentrations of CL3 (see Figure S5), where a new time constant emerged as the CL3 concentration increased. The increase of $R_{c t}$ in the presence of CL2 is due to the formation of a layer of inhibitor that prevents electronic interchange. An IE\% of 57.15\% was determined using Equation (2), comparable to the one determined by Tafel plots.

Table 3. Results of resistance and goodness fit values from impedance measurements.

\begin{tabular}{cccccc}
\hline Entry & $\mathbf{R}_{\mathbf{s}}$ & $\mathbf{R}_{\mathbf{c t}}$ & $\mathbf{R}_{\mathbf{1}}$ & Sum of Squares & IE\% \\
\hline $\mathrm{HCl} 0.5 \mathrm{M}$ & 3.049 & 1221 & - & 0.03649 & - \\
$\mathrm{HCl} 0.5 \mathrm{M}+\mathrm{CL} 2$ & 3.602 & 2850 & 19.83 & 0.24907 & 57.16 \\
\hline
\end{tabular}

\subsection{Investigation of the Morphology and Surperficial Composition of AB by SEM-EDS and XPS}

Figure 3 shows the SEM images of $\mathrm{AB}$ after immersion in $0.5 \mathrm{M} \mathrm{HCl}$ solutions in the absence and presence of CL2 at $50 \mathrm{ppm}$. The surface of the metal sample was significantly damaged in the $\mathrm{HCl}$ solution, indicating a high level of corrosion (see Figure 3a), while in the presence of CL2, the surface of $\mathrm{AB}$ was smoother, indicating a decreased corrosion rate (see Figure $3 b$ ). This phenomenon might be related to the formation of a stable protective layer of CL2 on the AB surface.
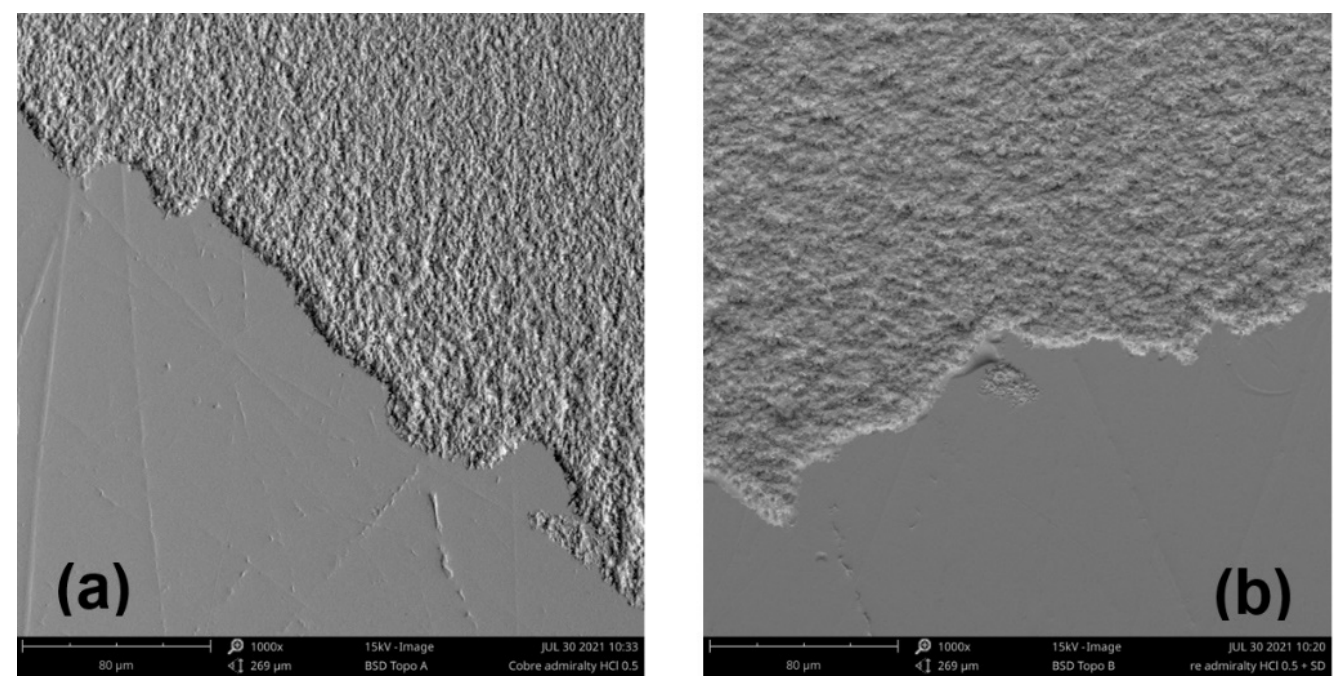

Figure 3. SEM micrographs of $\mathrm{AB}$ (a) in $0.5 \mathrm{M} \mathrm{HCl}$ and (b) in $0.5 \mathrm{M} \mathrm{HCl}$ with 50 ppm CL2.

Comparative XPS survey spectra for a polished metal sample (black line), AB immersed in $0.5 \mathrm{M} \mathrm{HCl}$ (red line), and $\mathrm{AB}$ immersed in $0.5 \mathrm{M} \mathrm{HCl}$ with $50 \mathrm{ppm} \mathrm{CL2} \mathrm{(blue} \mathrm{line)}$ are shown in Figure 4a. The inhibited-metal sample presented increased oxygen and carbon peaks, which can be mainly attributed to the organic composition of alkaloid-rich CL2 deposition on the surface. Moreover, nitrogen was only observed in the AB surface treated in the presence of CL2 confirming the presence of an alkaloid-rich layer in the surface (see Figure $4 \mathrm{~b}$ ). This layer attenuated the metallic register intensity of copper and zinc. As 
shown in Figure $4 \mathrm{c}$, the $\mathrm{C} 1 \mathrm{~s}$ core level presented several components such as $\mathrm{C}=\mathrm{C}$ binding at $284.4 \mathrm{eV}$ and $\mathrm{C}-\mathrm{C}$ at $285.12 \mathrm{eV}$. A shoulder was attributed to $\mathrm{C}-\mathrm{N}$ at $286.17 \mathrm{eV}$ and three additional peaks at $287.16 \mathrm{eV}, 288.5 \mathrm{eV}$, and $289.12 \mathrm{eV}$ associated with $\mathrm{C}-\mathrm{O}-\mathrm{C}, \mathrm{C}=\mathrm{O}$, and $\mathrm{O}-\mathrm{C}=\mathrm{O}$, respectively [51,52]. These types of bonds can be found in the tapsine alkaloid (see Figure S6), which has been isolated from the latex of C. lechleri [29]. The N1s high-resolution feature presents chemical environments for $\mathrm{C}-\mathrm{N}$ and $\mathrm{Cu}-\mathrm{N}$ binding energies at $400.45 \mathrm{eV}$ and $399.35 \mathrm{eV}$, respectively, an unprotonated $\mathrm{N}$ atom binding at $402.75 \mathrm{eV}$ followed by $\pi-\pi^{*}$ plasmon at $406.06 \mathrm{eV}$, as presented in Figure 4d [53-55]. Thus, the alkaloid-rich extract CL2 can form a protective film on the $\mathrm{AB} /$ solution interface via the $\mathrm{Cu}-\mathrm{N}$ coordination bonds through $\mathrm{N}$ lone pair and copper. This barrier film effectively hinders the corrosion of the $\mathrm{AB}$ substrate by the $\mathrm{HCl}$ medium. The $\mathrm{Cu} 2 \mathrm{p} 3$ feature presented a typical orbital splitting with an $\Delta \mathrm{E}=19.9 \mathrm{eV}$ for all the samples (see Figure S7a). The full width at half maximum (FWHM) changed from $1.293 \mathrm{eV}$ for the polished metal sample to $1.414 \mathrm{eV}$ for the corroded samples related to the formation of $\mathrm{Cu}(\mathrm{I})$. The latter was confirmed by the weak satellites at $947 \mathrm{eV}$. The behavior of $\mathrm{Zn} 2 \mathrm{p} 3$ presented a splitting orbital with an increment of the FWHM from $1.479 \mathrm{eV}$ for the polished $\mathrm{AB}$ to $1.863 \mathrm{eV}$ for the corroded samples as well as a shift on the $\mathrm{Zn} 2 \mathrm{p} 3 / 2$ peak of $0.394 \mathrm{eV}$, which was attributed to the formation of $\mathrm{Zn}$ (II) on the surface (see Figure $\mathrm{S} 7 \mathrm{~b}$ ).

(a)
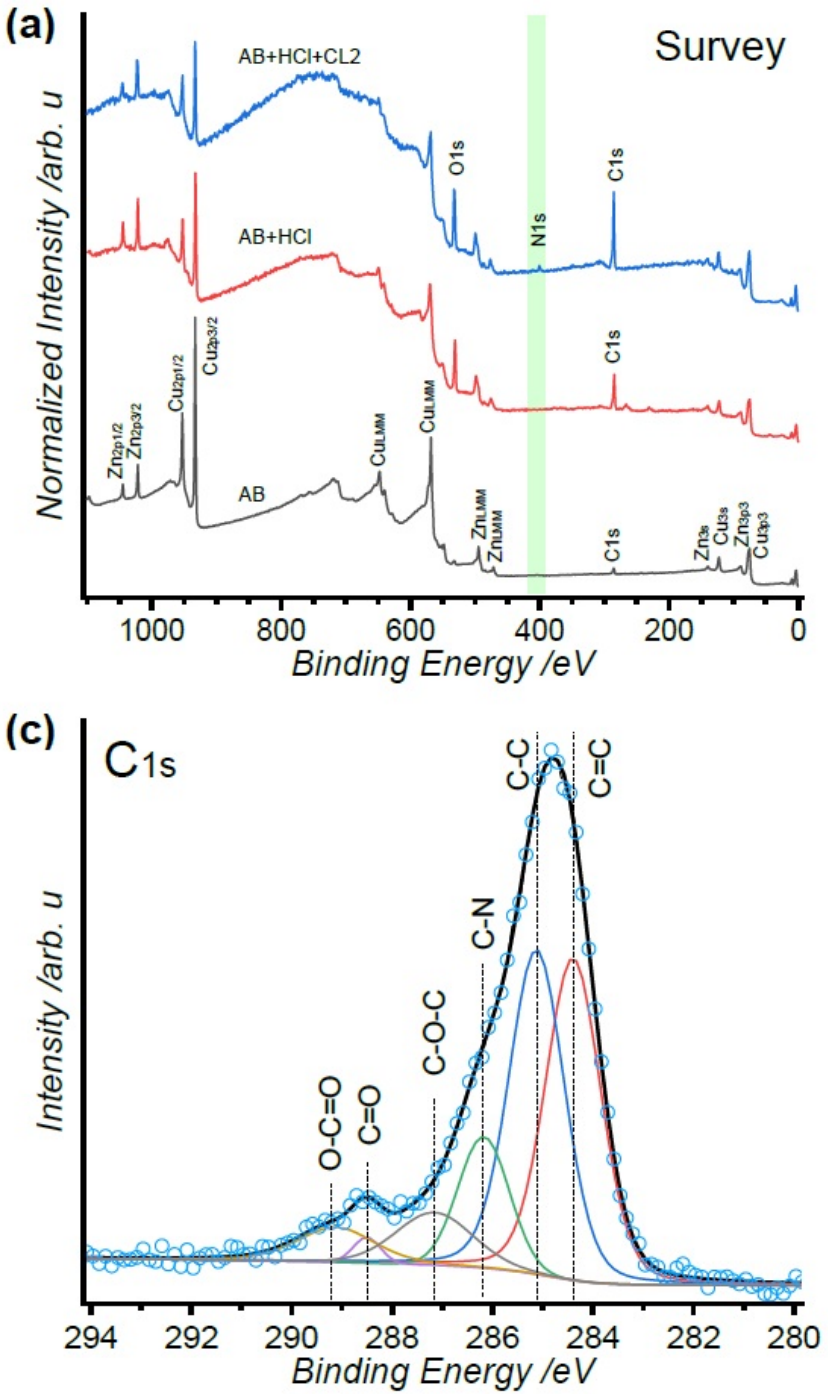
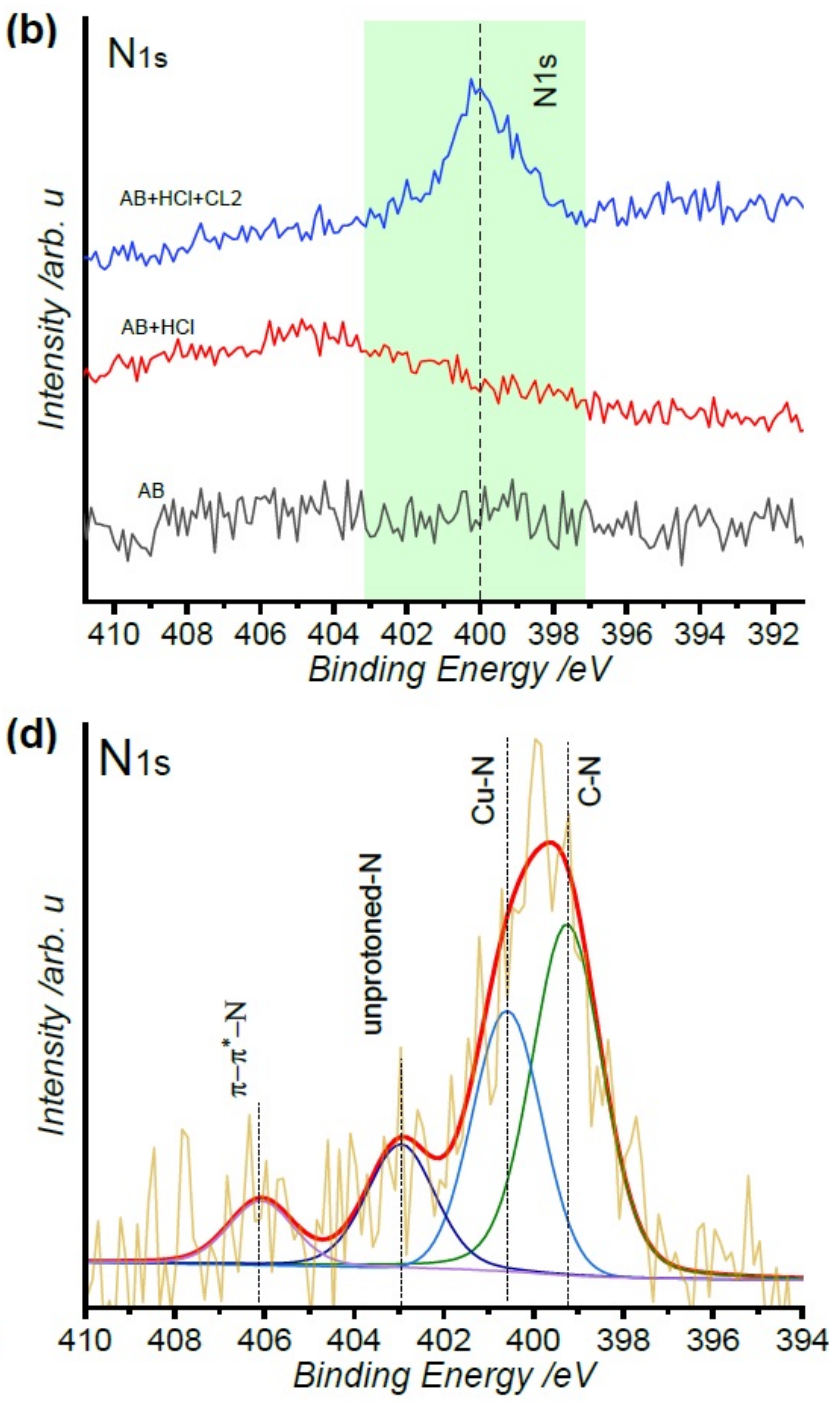

Figure 4. XPS spectra of the (a) survey scan and (b) N1s for a polished AB (black line), AB after immersion in $0.5 \mathrm{M} \mathrm{HCl}$ (red line), and $\mathrm{AB}$ after immersion in $0.5 \mathrm{M} \mathrm{HCl}$ with $50 \mathrm{ppm}$ CL2 (blue line). (c) C1s and (d) N1s spectra for the CL2 inhibited AB sample. 
The mechanism of brass corrosion in acidic media has been reported as a two-step dezincification process [56]. Initially, zinc is preferentially or even selectively dissolved [57] followed by a dissolution-redeposition of copper on the alloy surface, generating copperrich islands or porous films [58] as follows:

$$
\begin{gathered}
\mathrm{Cu}-\mathrm{Zn} \rightarrow \mathrm{Zn}^{2+}+2 \mathrm{e}^{-}+\mathrm{Cu} \\
\mathrm{Cu} \rightarrow \mathrm{Cu}^{+}+\mathrm{e}^{-} \\
2 \mathrm{Cu}^{+}+\mathrm{Zn} \rightarrow 2 \mathrm{Cu}+\mathrm{Zn}^{2+}
\end{gathered}
$$

Our experimental results agree with this process, as evidenced by the difference in the surface composition of $\mathrm{Cu}(70.48 \%)$ and $\mathrm{Zn}(29.42 \%)$ for a polished metal sample (see Figure S8) compared to the composition of $\mathrm{Cu}(82.12 \%)$ and $\mathrm{Zn}(17.88 \%)$ for $\mathrm{AB}$ treated in $0.5 \mathrm{M} \mathrm{HCl}$ (see Figure S9). The inhibition capacity of CL2 is attributed to the molecular structure of natural products that were enriched in alkaloid compounds. Tapsine structure shows two aromatic rings with $\pi$ electrons and heteroatoms such as nitrogen and oxygen, that can interact with the d-orbitals of the metal by their lone pairs to form a well-adsorbed organic film. The layer, formed on the surface, can isolate the alloy from the corrosive solution, which has been observed in mixed-type inhibitors [59-62] as evidenced by the conserved surface composition of $\mathrm{Cu}(69.70 \%)$ and $\mathrm{Zn}(30.30 \%)$ for $\mathrm{AB}$ treated in $0.5 \mathrm{M} \mathrm{HCl}$ with 50 ppm CL2 (see Figure S10). Furthermore, many alkaloids as well as other natural products form complexes with $\mathrm{Cu}+$ or $\mathrm{Zn}^{2+}$ that prevents the formation of soluble metallic chlorides, limiting the overall oxidation process [63]. A comparison of the $\mathrm{AB}$ samples by the naked eye after immersion in $0.5 \mathrm{M} \mathrm{HCl}$ solution in the absence and presence of CL2 at 50 ppm showed the inhibition potential of dragon's blood extracts (see Figure S11). From an industrial point of view, the formulation of corrosion inhibitors based on C. lechleri latex offers two opportunities-the valorization of a non-edible natural source and the diversification of the availability of corrosion inhibitors for the chemical treatment of equipment in different industrial sectors. These green corrosion inhibitors might provide an option for the corrosion mitigation in the cleaning process of heat exchangers increasing their lifecycle.

\section{Conclusions}

In summary, lyophilization, chloroform Soxhlet extraction, and supercritical $\mathrm{CO}_{2}$ antisolvent extraction techniques were successfully employed to obtain novel green $C$. lechleri solid corrosion inhibitors of $\mathrm{AB}$ in $0.5 \mathrm{M} \mathrm{HCl}$ media. CL1, which is the dry $C$. lechleri latex, showed the presence of alkaloid and phenolic compounds with an IE\% of $30.48 \%$. Microparticles of CL3 enriched in phenolic content provided an IE\% of $48.93 \%$, while CL2 was enriched in alkaloid compounds showing an IE\% of $57 \%$. Adsorption onto the surface of $\mathrm{AB}$ of the alkaloid molecules in CL2 was proposed as the mechanism of corrosion by slowing down the dezincification process of the metal sample. Further purification and processing of CL2 should improve its solubility and corrosion-inhibition efficiency. Studies at various concentrations and temperatures as well as computational simulations are performing by our group to obtain information about the adsorption process and thermodynamics.

Supplementary Materials: The following are available online: Figure S1. Pilot plant of supercritical $\mathrm{CO}_{2}$ antisolvent extraction of CL3. Table S1. Conditions of supercritical $\mathrm{CO}_{2}$ antisolvent extraction of CL3. Figure S2. Photographs of solid extracts obtained from C. lechleri by lyophilization, solvent extraction, and supercritical $\mathrm{CO}_{2}$ antisolvent extraction. Figure S3. Potentiodynamic polarization plots of $\mathrm{AB}$ in $0.5 \mathrm{M} \mathrm{HCl}$ in the presence of CL3 at several concentrations at $25^{\circ} \mathrm{C}$. Figure S4. Microphotography of CL3 spherical particles. Table S2. Tafel polarization parameters for AB in $0.5 \mathrm{M} \mathrm{HCl}$ with CL3 at concentration of $50 \mathrm{ppm}-200 \mathrm{ppm}$ at $25{ }^{\circ} \mathrm{C}$. Figure S5. Bode diagrams of $\mathrm{AB}$ at $\mathrm{E}_{\mathrm{corr}}$ in $0.5 \mathrm{M} \mathrm{HCl}$ at various concentrations of CL3. Figure S6. Chemical structure of tapsine. Figure S7. Cu2p3 and Zn2p3 XPS spectra for a polished AB, AB after immersion in $0.5 \mathrm{M} \mathrm{HCl}$, and 
$\mathrm{AB}$ after immersion in $0.5 \mathrm{M} \mathrm{HCl}$ with 50 ppm CL2. Figure S8. EDS spectrum of a polished AB sample. Figure S9. EDS spectrum of AB after immersion in $0.5 \mathrm{M} \mathrm{HCl}$. Figure S10. EDS spectrum of $\mathrm{AB}$ after immersion in $0.5 \mathrm{M} \mathrm{HCl}$ with $50 \mathrm{ppm}$ CL2. Figure S11. Photographs of $\mathrm{AB}$ after immersion in $0.5 \mathrm{M} \mathrm{HCl}$ and $0.5 \mathrm{M} \mathrm{HCl}$ with 50 ppm CL2.

Author Contributions: A.P.-C., C.C.-M., P.C.-P., M.A.M. and M.d.C.G. conceived and designed the experiments. A.P.-C., C.C.-M., R.L., C.R., M.A.M. and M.d.C.G. performed the experiments. All authors analyzed the data. A.P.-C., C.C.-M., P.C.-P., C.R., M.A.M., M.R. and M.d.C.G. wrote the draft manuscript. A.P.-C. supervised the writing process and edited the manuscript. All authors have read and agreed to the published version of the manuscript.

Funding: This research was funded by Corporación Ecuatoriana para el Desarrollo de la Investigación y Academia-CEDIA, grant number CEPRA XV-2021-015.

Data Availability Statement: Data are available from the authors upon request.

Acknowledgments: We thank Alfredo Viloria, Paola Ordoñez, and Ruth Oropeza for the valuable discussion. We thank Elizabeth Mariño for the SEM images and EDS spectra. The authors would like to thank to Corporación Ecuatoriana para el Desarrollo de la Investigación y Academia-CEDIA for the financial support given to the present research, development, and innovation work through its CEPRA program, especially for the CEPRA XV-2021-015 fund.

Conflicts of Interest: The authors declare no conflict of interest.

Sample Availability: Samples of the compounds are available from the authors.

\section{References}

1. Revie, R.W.; Uhlig, H.H. Corrosion and Corrosion Control; John Wiley \& Sons, Inc.: Hoboken, NJ, USA, 2008; ISBN 9780470277270.

2. Callister, W.D.; Rethwisch, D.G. Materials Science and Engineering an Introduction, 9th ed.; John Wiley \& Sons, Inc.: Hoboken, NJ, USA, 2014; ISBN 9781118324578.

3. Shah, R.K.; Sekuli, D.P. Fundamentals of Heat Exchanger Design; John Wiley \& Sons, Inc.: Hoboken, NJ, USA, 2003; ISBN 9780470172605.

4. Chung, D.D. Materials for thermal conduction. Appl. Therm. Eng. 2001, 21, 1593-1605. [CrossRef]

5. Brass Alloy UNS C44300. Available online: https://www.azom.com/article.aspx?ArticleID=6371 (accessed on 17 November 2021).

6. Sherif, E.-S.M.; Erasmus, R.M.; Comins, J.D. Inhibition of copper corrosion in acidic chloride pickling solutions by 5-(3aminophenyl)-tetrazole as a corrosion inhibitor. Corros. Sci. 2008, 50, 3439-3445. [CrossRef]

7. Meroufel, A.A. Corrosion Control during Acid Cleaning of Heat Exchangers. In Corrosion and Fouling Control in Desalination Industry; Springer International Publishing: Cham, Germany, 2020; pp. 209-224.

8. Ramana Murthy, R.V.V.; Katari, N.K.; Satya Sree, N.; Jonnalagadda, S.B. A novel protocol for reviving of oil and natural gas wells. Pet. Res. 2019, 4, 276-281. [CrossRef]

9. Zhu, M.-D.; Xing, N.; Ai, L.-S.; Wang, J.; Chen, X.-Y.; Jiao, Q.-Z.; Shi, L. Development of polyacid corrosion inhibitor with 2-vinylpyridine residue. Chem. Pap. 2021, 75, 6127-6135. [CrossRef]

10. Taha, K.K.; Mohamed, M.E.; Khalil, S.A.; Talab, S.A. Inhibition of Brass Corrosion in Acid Medium Using Thiazoles. Int. Lett. Chem. Phys. Astron. 2013, 14, 87-102. [CrossRef]

11. Benali, O.; Zebida, M.; Benhiba, F.; Zarrouk, A.; Maschke, U. Carbon steel corrosion inhibition in H2SO4 $0.5 \mathrm{M}$ medium by thiazole-based molecules: Weight loss, electrochemical, XPS and molecular modeling approaches. Colloids Surfaces A Physicochem. Eng. Asp. 2021, 630, 127556. [CrossRef]

12. Satpati, A.K.; Reddy, A.V.R. Electrochemical Study on Corrosion Inhibition of Copper in Hydrochloric Acid Medium and the Rotating Ring-Disc Voltammetry for Studying the Dissolution. Int. J. Electrochem. 2011, 2011, 173462. [CrossRef]

13. Qiang, Y.; Li, H.; Lan, X. Self-assembling anchored film basing on two tetrazole derivatives for application to protect copper in sulfuric acid environment. J. Mater. Sci. Technol. 2020, 52, 63-71. [CrossRef]

14. Qiang, Y.; Guo, L.; Li, H.; Lan, X. Fabrication of environmentally friendly Losartan potassium film for corrosion inhibition of mild steel in $\mathrm{HCl}$ medium. Chem. Eng. J. 2021, 406, 126863. [CrossRef]

15. Messina, E.; Giuliani, C.; Pascucci, M.; Riccucci, C.; Staccioli, M.P.; Albini, M.; Di Carlo, G. Synergistic Inhibition Effect of Chitosan and L-Cysteine for the Protection of Copper-Based Alloys against Atmospheric Chloride-Induced Indoor Corrosion. Int. J. Mol. Sci. 2021, 22, 10321. [CrossRef]

16. Stupnišek-Lisac, E.; Gazivoda, A.; Madžarac, M. Evaluation of non-toxic corrosion inhibitors for copper in sulphuric acid. Electrochim. Acta 2002, 47, 4189-4194. [CrossRef]

17. Yang, H.-M. Role of Organic and Eco-Friendly Inhibitors on the Corrosion Mitigation of Steel in Acidic Environments-A State-of-Art Review. Molecules 2021, 26, 3473. [CrossRef] [PubMed]

18. Raja, P.B.; Sethuraman, M.G. Natural products as corrosion inhibitor for metals in corrosive media-A review. Mater. Lett. 2008, 62, 113-116. [CrossRef] 
19. Qiang, Y.; Zhang, S.; Tan, B.; Chen, S. Evaluation of Ginkgo leaf extract as an eco-friendly corrosion inhibitor of X70 steel in $\mathrm{HCl}$ solution. Corros. Sci. 2018, 133, 6-16. [CrossRef]

20. Davis, G.D.; Von Fraunhofer, J.A.; Krebs, L.A.; Dacres, C.M. The use of tobacco extracts as corrosion inhibitors. NACE-Int. Corros. Conf. Ser. 2001, 2001-March, NACE-01558.

21. Ebenso, E.E.; Eddy, N.O.; Odiongenyi, A.O. Corrosion inhibitive properties and adsorption behaviour of ethanol extract of Piper guinensis as a green corrosion inhibitor for mild steel in H2SO4. Afr. J. Pure Appl. Chem. 2008, 2, 107-115.

22. Okafor, P.C.; Ikpi, M.E.; Ekanem, U.I.; Ebenso, E. Effects of extracts from nauclea latifolia on the dissolution of carbon steel in H2SO4 solutions. Int. J. Electrochem. Sci. 2013, 8, 12278-12286.

23. Kliskic, M.; Radosevic, J.; Gudic, S.; Katalinic, V. Aqueous extract of Rosmarinus officinalis L. as inhibitor of $\mathrm{Al} \pm \mathrm{Mg}$ alloy corrosion in chloride solution. J. Appl. Electrochem. 2000, 30, 823-830. [CrossRef]

24. Berković, K.; Kovač, S.; Vorkapić-Furač, J. Natural compounds as environmentally friendly corrosion inhibitors of aluminium. Acta Aliment. 2004, 33, 237-247. [CrossRef]

25. Ostovari, A.; Hoseinieh, S.M.; Peikari, M.; Shadizadeh, S.R.; Hashemi, S.J. Corrosion inhibition of mild steel in $1 \mathrm{M} \mathrm{HCl} \mathrm{solution}$ by henna extract: A comparative study of the inhibition by henna and its constituents (Lawsone, Gallic acid, $\alpha$-d-Glucose and Tannic acid). Corros. Sci. 2009, 51, 1935-1949. [CrossRef]

26. Subramanyam, N.C.; Sheshadri, B.S.; Mayanna, S.M. Quinine and strychnine as corrosion inhibitors for copper in sulphuric acid. Br. Corros. J. 1984, 19, 177-180. [CrossRef]

27. Kleindl, P.A.; Xiong, J.; Hewarathna, A.; Mozziconacci, O.; Nariya, M.K.; Fisher, A.C.; Deeds, E.J.; Joshi, S.B.; Middaugh, C.R.; Schöneich, C.; et al. The Botanical Drug Substance Crofelemer as a Model System for Comparative Characterization of Complex Mixture Drugs. J. Pharm. Sci. 2017, 106, 3242-3256. [CrossRef]

28. De Marino, S.; Gala, F.; Zollo, F.; Vitalini, S.; Fico, G.; Visioli, F.; Iorizzi, M. Identification of minor secondary metabolites from the latex of Croton lechleri (Muell-Arg) and evaluation of their antioxidant activity. Molecules 2008, 13, 1219-1229. [CrossRef] [PubMed]

29. Milanowski, D.J.; Winter, R.E.K.; Elvin-Lewis, M.P.F.; Lewis, W.H. Geographic distribution of three alkaloid chemotypes of Croton lechleri. J. Nat. Prod. 2002, 65, 814-819. [CrossRef] [PubMed]

30. Jones, K. Review of Sangre de Drago (Croton lechleri)-A South American Tree Sap in the Treatment of Diarrhea, Inflammation, Insect Bites, Viral Infections, and Wounds: Traditional Uses to Clinical Research. J. Altern. Complement. Med. 2003, 9, 877-896. [CrossRef] [PubMed]

31. Felipe, M.B.M.C.; Silva, D.R.; Martinez-Huitle, C.A.; Medeiros, S.R.B.; Maciel, M.A.M. Effectiveness of Croton cajucara Benth on corrosion inhibition of carbon steel in saline medium. Mater. Corros. 2013, 64, 530-534. [CrossRef]

32. Rajeswari, V.; Kesavan, D.; Gopiraman, M.; Viswanathamurthi, P.; Poonkuzhali, K.; Palvannan, T. Corrosion inhibition of Eleusine aegyptiaca and Croton rottleri leaf extracts on cast iron surface in $1 \mathrm{M} \mathrm{HCl}$ medium. Appl. Surf. Sci. 2014, 314, 537-545. [CrossRef]

33. Geethamani, P.; Kasthuri, P.K.; Aejitha, S.; Geethamani, P. Mitigation of mild steel corrosion in $1 \mathrm{M}$ sulphuric acid medium by Croton Sparciflorus A green inhibitor. Chem. Sci. Rev. Lett. 2014, 2, 507-516.

34. Sarker, S.D.; Nahar, L. (Eds.) Natural Products Isolation, 3rd ed.; Humana Press: London, UK, 2012; Volume 1, ISBN 9781627032384.

35. Azmir, J.; Zaidul, I.S.M.; Rahman, M.M.; Sharif, K.M.; Mohamed, A.; Sahena, F.; Jahurul, M.H.A.; Ghafoor, K.; Norulaini, N.A.N.; Omar, A.K.M. Techniques for extraction of bioactive compounds from plant materials: A review. J. Food Eng. 2013, 117, 426-436. [CrossRef]

36. Gómez-García, R.; Campos, D.A.; Aguilar, C.N.; Madureira, A.R.; Pintado, M. Valorisation of food agro-industrial by-products: From the past to the present and perspectives. J. Environ. Manag. 2021, 299, 113571. [CrossRef]

37. Lampakis, D.; Skenderidis, P.; Leontopoulos, S. Technologies and Extraction Methods of Polyphenolic Compounds Derived from Pomegranate (Punica granatum) Peels. A Mini Review. Processes 2021, 9, 236. [CrossRef]

38. Kawasaki, H.; Shimanouchi, T.; Kimura, Y. Recent Development of Optimization of Lyophilization Process. J. Chem. 2019, 2019, 9502856. [CrossRef]

39. Reverchon, E.; De Marco, I. Supercritical fluid extraction and fractionation of natural matter. J. Supercrit. Fluids 2006, 38, 146-166. [CrossRef]

40. Meneses, M.A.; Caputo, G.; Scognamiglio, M.; Reverchon, E.; Adami, R. Antioxidant phenolic compounds recovery from Mangifera indica L. by-products by supercritical antisolvent extraction. J. Food Eng. 2015, 163, 45-53. [CrossRef]

41. Guamán-Balcázar, M.C.; Montes, A.; Fernández-Ponce, M.T.; Casas, L.; Mantell, C.; Pereyra, C.; Martínez de la Ossa, E. Generation of potent antioxidant nanoparticles from mango leaves by supercritical antisolvent extraction. J. Supercrit. Fluids 2018, 138, 92-101. [CrossRef]

42. Vaisberg, A.J.; Milla, M.; Planas, M.C.; Cordova, J.L.; de Agusti, E.R.; Ferreyra, R.; Mustiga, M.C.; Carlin, L.; Hammond, G.B. Taspine is the cicatrizant principle in Sangre de Grado extracted from Croton lechleri. Planta Med. 1989, 55, 140-143. [CrossRef]

43. Palanisamy, G. Corrosion Inhibitors. In Corrosion Inhibitors; IntechOpen: London, UK, 2019.

44. Fateh, A.; Aliofkhazraei, M.; Rezvanian, A.R. Review of corrosive environments for copper and its corrosion inhibitors. Arab. J. Chem. 2020, 13, 481-544. [CrossRef]

45. Baldino, L.; Della Porta, G.; Osseo, L.S.; Reverchon, E.; Adami, R. Concentrated oleuropein powder from olive leaves using alcoholic extraction and supercritical CO2 assisted extraction. J. Supercrit. Fluids 2018, 133, 65-69. [CrossRef] 
46. Zhang, J.; Huang, Y.; Liu, D.; Gao, Y.; Qian, S. Preparation of apigenin nanocrystals using supercritical antisolvent process for dissolution and bioavailability enhancement. Eur. J. Pharm. Sci. 2013, 48, 740-747. [CrossRef] [PubMed]

47. Deng, Y.; Sun, J.; Wang, F.; Sui, Y.; She, Z.; Zhai, W. Effect of particle size on solubility, dissolution rate, and oral bioavailability: Evaluation using coenzyme Q10 as naked nanocrystals. Int. J. Nanomed. 2012, 7, 5733-5744. [CrossRef]

48. Hwang, S.-J.; Kim, M.-S.; Kim, J.-S.; Park, H.J.; Cho, W.K.; Cha, K.-H. Enhanced bioavailability of sirolimus via preparation of solid dispersion nanoparticles using a supercritical antisolvent process. Int. J. Nanomed. 2011, 6, 2997-3009. [CrossRef] [PubMed]

49. Quraishi, M.A.; Chauhan, D.S.; Saji, V.S. Heterocyclic biomolecules as green corrosion inhibitors. J. Mol. Liq. 2021, $341,117265$. [CrossRef]

50. Jüttner, K. Electrochemical impedance spectroscopy (EIS) of corrosion processes on inhomogeneous surfaces. Electrochim. Acta 1990, 35, 1501-1508. [CrossRef]

51. Yang, L.; Tian, J.; Meng, J.; Zhao, R.; Li, C.; Ma, J.; Jin, T. Modification and Characterization of Fe3O4 Nanoparticles for Use in Adsorption of Alkaloids. Molecules 2018, 23, 562. [CrossRef] [PubMed]

52. Singh, P.; Srivastava, V.; Quraishi, M.A. Novel quinoline derivatives as green corrosion inhibitors for mild steel in acidic medium: Electrochemical, SEM, AFM, and XPS studies. J. Mol. Liq. 2016, 216, 164-173. [CrossRef]

53. Lebrini, M.; Suedile, F.; Salvin, P.; Roos, C.; Zarrouk, A.; Jama, C.; Bentiss, F. Bagassa guianensis ethanol extract used as sustainable eco-friendly inhibitor for zinc corrosion in 3\% NaCl: Electrochemical and XPS studies. Surf. Interfaces 2020, 20, 100588. [CrossRef]

54. Yang, D.; Liu, S.H.; Shao, Y.P.; Di Xu, S.; Zhao, L.L.; Liao, Q.Q.; Ge, H.H. Electrochemical and XPS studies of alkyl imidazoline on the corrosion inhibition of carbon steel in citric acid solution. Corros. Rev. 2016, 34, 295-304. [CrossRef]

55. Tan, B.; Xiang, B.; Zhang, S.; Qiang, Y.; Xu, L.; Chen, S.; He, J. Papaya leaves extract as a novel eco-friendly corrosion inhibitor for $\mathrm{Cu}$ in $\mathrm{H} 2 \mathrm{SO} 4$ medium. J. Colloid Interface Sci. 2021, 582, 918-931. [CrossRef]

56. Polunin, A.V.; Pchelnikov, A.P.; Losev, V.V.; Marshakov, I.K. Electrochemical studies of the kinetics and mechanism of brass dezincification. Electrochim. Acta 1982, 27, 467-475. [CrossRef]

57. Burzyńska, L. Comparison of the spontaneous and anodic processes during dissolution of brass. Corros. Sci. 2001, 43, 1053-1069. [CrossRef]

58. Zhou, P.; Ogle, K. The Corrosion of Copper and Copper Alloys. In Encyclopedia of Interfacial Chemistry; Elsevier: Amsterdam, The Netherlands, 2018; pp. 478-489.

59. Rani, B.E.A.; Basu, B.B.J. Green Inhibitors for Corrosion Protection of Metals and Alloys: An Overview. Int. J. Corros. 2012, 2012, 1-15. [CrossRef]

60. Xu, Q.-M.; Wang, D.; Han, M.-J.; Wan, L.-J.; Bai, C.-L. Direct STM Investigation of Cinchona Alkaloid Adsorption on Cu(111). Langmuir 2004, 20, 3006-3010. [CrossRef] [PubMed]

61. Cai, L.; Fu, Q.; Shi, R.; Tang, Y.; Long, Y.-T.; He, X.-P.; Jin, Y.; Liu, G.; Chen, G.-R.; Chen, K. 'Pungent' Copper Surface Resists Acid Corrosion in Strong HCl Solutions. Ind. Eng. Chem. Res. 2014, 53, 64-69. [CrossRef]

62. Singh, M.M.; Rastogi, R.B.; Upadhyay, B.N. Inhibition of Copper Corrosion in Aqueous Sodium Chloride Solution by Various Forms of the Piperidine Moiety. Corrosion 1994, 50, 620-625. [CrossRef]

63. Li, H.-J.; Zhang, W.; Wu, Y.-C. Anti-Corrosive Properties of Alkaloids on Metals. In Alkaloids-Their Importance in Nature and Human Life; IntechOpen: London, UK, 2019. 